\title{
Locating Identity Crisis in Postcolonial Theory: Fanon And Said
}

\author{
Saman Abdulqadir Dizayi ${ }^{1}$ \\ ${ }^{1}$ Erbil Polytechnic University, Iraq
}

\begin{abstract}
ARTICLE INFO
Keywords:

Post colonialism, Identity, Franz Fanon, Edward Said Introduction (TNR 14pt., bold)
\end{abstract}

\begin{abstract}
This paper presents postcolonial theory and its emergence from the fallout of colonial impact on the world after WWII. It reveals insight into historical actualities and traces the sequential line of thought and speculation of the period, how the issue of representation and self determination is displayed in theoretical argument. At that point it clarifies the issue of identity in the postcolonial theoretical line, and its critical role as the real issue of postcolonial theory. The paper additionally uncovers how scholars explore the situation of recognition and self-recognizable proof. Finally, it clarifies significant theorist contentions about identity independently and in agreement to the sequential course of events, for example, Frantz Fanon, Edward Said. It notes how every scholar viewed and hypothesized the issue of identity and to what extent these speculations are essential in postcolonial studies.
\end{abstract}

\section{Introduction}

Postcolonial theory, or postcolonialism, can be characterized as the investigation of colonial impact, and its legacy from post-WWII to the present day. It explores the socio-political, psychological, and political impact of the colonial legacy. Postcolonial theory also handles the investigation of the conduct of recently free social orders, as they struggle for self determination. It considers the test and refusal of colonial social and political guidelines, and frameworks that were abandoned and overwhelmed colonizers for quite a while. Postcolonial theory additionally examining literary types and cultural viewpoints identified with the cutting edge after colonialism wanes, all through diverse ways and strategies. Ashcroft et al. (1989) affirm that postcolonial literary theory appears after the failure of Western theory to bargain adequately the complications and different cultural determinations of postcolonial composing [1]. Since the publication of Said's Orientalism in the late of 1970s, postcolonial theory and studies have taken an interest in the ranges of sociopolitical and literary feedback, with alternate points of view and contentions. The distinction of the fields and the different states of postcolonial circumstance have received assorted responses in both postcolonial theory and studies.

Darby and Paolini (1994) characterize post-colonialism as hunting down or recovering the moral and passionate position in addressing Western advancement, directed by experts of the developing nations, or researchers from West. The movement of such a procedure is on the edge, resulting in a noteworthy method and a progressive viewpoint;

$\square$ Corresponding Author E-Mail Address: Saman.dizayi@epu.edu.iq 
"postcolonialism has tended to be allembracing and, ironically, it has acted to "colonize" and refashion aspects of scholarship previously the domain of Western academe, such as literature, history, and social theory. Ideas about the emotional stance and radical space cleared by postcolonialism" [2]

Thus, scholars find numerous perspectives that focus on managing theoretical application in distinctive postcolonial fields. It is worth mentioning that colonial power administered to over $80 \%$ of the world for over three centuries before its breakdown following World War II. The impact of the imperial period and the aftermath of decolonization coordinated the literary and theoretical enthusiasm for its diverse issues, in which the much touted encounters of the ex-colonized countries recommended that the postcolonial era could be a free world. Thus, there is no altered physical definition for the term postcolonial since, as Ashcroft et al. (1989) argued, the colonized cultures were influenced completely by the colonial movement from the start of colonialism up to the present day[3]. Many experts and scholars assumed a part in the advancement of postcolonial theory; Innes names four exceptional figures that "show up over and over as scholars who have formed postcolonial theory: Frantz Fanon, Edward Said, Homi Bhabha, and Gayatri Chakravorty Spivak" [4]. Thus, postcolonial theory and response, in the lion's share of critics and scholars, emerges from the legacy of colonialism, as Bhabha (1994) attests; postcolonial perspectives rise up out of the colonial evidence of third world countries and the talks of "minorities" inside of the geopolitical divisions. These points of view include cutting edge ideological talks that endeavor to standardize the administration of the equivalent development, histories of social orders, race and nations .[5]

Hence, postcolonial theory and studies manage distinctive decolonization groups and propensities, however gathered inside of its fringe and contentions. The guarantee of postcolonial theory is bound to the perspectives and encounters of nations that have lived and experienced colonial powers. As Young (2001) argues, postcolonial feedback focuses on authoritarian control that was in power in the world [6]. Thus, postcolonial theory and feedback fails to include the precise encounters of colonial history; rather, it concerns the aftermath of colonialism. Additionally, postcolonial theory and studies inspect social orders and nations whose encounters battle for a space in a world in which the question of recognition turns into a primary dilemma.

Thus, the most disputable and significant issues of postcolonial theory and studies is the subject of identity. Since the outbreaks of independence battles of recently liberated nations, for their own particular identity, and with the expansion of settler numbers and the constitution of countries with distinctive cultural diversities, the topic of identity has risen to the top. Jones Brockimeier and Donal Carbaugh (2001) argue that the concept of identity occupies a large part of scholarly issues that have been contemplated in an assortment of differing theoretical perspectives. The ascent of the topic of identity turned into a noteworthy topic in theory and literary studies as well as stretching out to the entire range of life. The larger part of scholars and critics have related the complication of identity issues to the colonial effect, as Pieterse (2002) argues: at the season of decolonization, when imperial identities were decentered, the subject of identity became a basic and noticeable topic" [7]. Theoretically, identity is argued primarily in the connection between self and other and where instability resides inside of the confinement of the space between identities, as Stuart Hall observes: "character develops as a sort of troubled space or an indecisive inquiry in that space, between various meeting talks" [8]. Scholars reached a more noteworthy aim: to clarify the postcolonial identity crisis in light of its role as an essential component of the many-sided quality, coming into being after colonialism. Ashcroft, Griffiths, and Tiffin (1989) affirm identity 
inquiry as a "noteworthy part of postcolonial literature, in which it manages place and displacement. Inside of this specific postcolonial crisis of identity, the worry emerges with the improvement or recuperation of a powerful relationship recognizing the middle of self and place" [9]. Thus, scholars have become interested in inspecting and researching, explaining and presenting contentions about this significant issue.

\section{Theoretical Viewpoints on Postcolonial Identity: Fanon and Said}

Regarding theorists arguments about identity formation and its crisis in postcolonial era, there are different analyses and contentions, but with a quiet consent that the existence and complexities of the dilemma forms the primary outcome and explicit consequences of colonialism. We begin with Fanon, whose view of identity was based on the fierce historical association of the colonized and the colonizers. His contentions identified the impact of the savage legacy of imperialism on the identity production of the colonized as argued by Richards (2011): that libration is not adequate to remove the impact of colonialism and to recapture the sensation of identity [10]. Fanon, in his theoretical contentions, ascribes a more noteworthy aim in the outcomes of colonialism and the change framed by the experience of immigration; he analyzes, as Ryan (2012) states, the experience of wearing "white masks" to cope with the West, or turning from one's own particular identity to appear to the colonizer in an image that prevents all debased attributes that show the colonized as "primitive" [11]. Drawing on the 1950's philosophical ground of existentialism; "Existentialism", the philosophical theory which holds a further set of categories, governed by the norm of authenticity, is necessary to grasp human existence. central to existentialism, it is equally true that all the themes popularly associated with existentialism-dread, boredom, alienation, the absurd, freedom, commitment, nothingness, and so on-find their philosophical significance in the context of the search for a new categorial framework, together with its governing norm, Fanon's theoretical contention exhibited through his vow to the Algerian transformation, in which his thought regarding identity development came out through opposition to the colonial legacy of racist based hostility against Africans. In Black Skin White Masks (1967), Fanon uncovers the black man's worries in the breakout of postcolonial period. His treatment of racism psychoanalytically is an ironic perusing of the black man's breakdown. His contention provocatively advises that black men attempt to look like or to appear whites; yet in the guarantees of white men, black men will not be endorsed. This negative perspective from Fanon derives from the bases of a time when a group judged blacks by their color.

"Every colonized people-in other words, every people in whose soul an inferiority complex has been created by the death and burial of its local cultural originality - finds itself face to face with the language of the civilizing nation; that is, with the culture of the mother country. The colonized is elevated above his jungle status in proportion to his adoption of the mother country's cultural standards. He becomes whiter as he renounces his blackness, his jungle.’[12]

The sort of racism argued by Fanon in the imagistic title Black Skin White Masks, as Larose T. Parris (2015) notes, clearly pronounces the system Fanon uses to investigate the colonized crisis of "self-recognizable proof" [13]. To Fanon the genuine identity is confined inside of the comparison of black and white, the skin and the veil. The black man wears a veil under the effect of colonial impact, which contorts blacks to act naturally. Fanon relates this to the outcomes of colonialism when he argues white man's advancement and culture have implemented an "existential digression on the negro" [14]. We might consider a finding from this Fanonian view, that Western power profoundly embedded the colonized presence in their 
culture as well as in the individual's self-regard, seeing himself unequal to the colonizer or, as such, the colonizer perspectives unrivaled, which forces this predominance over the colonized.

The significance of identity becomes a hazardous crisis inside the confinement of refusal and the conflict to demonstrate one's self to the other. This treatment of Western power to subjects made a psychological and dysfunctional behavior. As Richards (2011) calls attention to the "assaults the identity substance in the colonized by instigating a type of psychological illness" [15] and by that he is refereeing to Fanon's (1967) psychological analysis of the effects of colonial violence on colonized people;

“The Negro's behaviour makes him akin to an obsessive neurotic type, or, if one prefers, he puts himself into a complete situational neurosis. In the man of colour there is a constant effort to run away from his own individuality, to annihilate his own presence, , The attitude of the Black man toward the white, or toward his own race, often duplicates almost completely a constellation of delirium, frequently bordering on the region of the pathological. [16]

To challenge the problem of colonial impact, Fanon focuses on the crisis of identity as found in the contention of hovering on one being or seen as the "other." Fanon (1967) argues that "a black man thinks himself to become whiter by utilizing the dialect of the white man, by taking upon himself the world of the other" [17]. Therefore, during to the struggle against colonization, blacks under the psychological weight of their mediocrity attempt to demonstrate recognizable proof that they are equal to whites, and "need to demonstrate to white men no matter what, the wealth of their idea, the equivalent estimation of their insight" 18].

This sort of black men's conduct, to imitate the colonizer, is the aftereffect of the colonial impact on their awareness, which evidently influenced by methodical strategy of white man's goal, to sum up and apply the colonial belief system of power and predominance on the other, to make the colonized oblivious to the genuine distinguishing proof that separates them and to give them the merited assessment as people, not as becoming an impersonation of the white, thus valueless. The focal point of Fanon's discussion is that the white man, or colonizer, purposefully solidifies the awareness of the black man, or colonized, by enforcing their discourse during colonization, which devalues the colonized with a specific end goal: to show how they are unequal. The blacks or colonized are obliged to "surmise that they are by nature irrational and uncultured, lacking ethical qualities; so, they require education, civilization to be brought to them. This degradation requires the affirmation of identity and ritual of local methods for living and history" [19]. In general, Fanon's Black Skin, White Masks investigates the brainwashing of colonialism and uncovers the impacts it made on the awareness of colonized individuals, and the resulting disarray and loss of identity.

Similar to Fanon's idea of the power domination of colonizers, and its impact on the colonized culturally, financially, psychologically, and forcing their prevalence, Said, in Orientalism (1978), develops his contention of separating the world into two binaries: Orient and Occident, East and West. While Fanon's contentions for the most part concern the psychoanalytic zone, Said connected with political discourse. Constructing his argument with respect to Foucaultian thought on power and knowledge, Said translates the connection between colonial powers and colonized individuals and countries. His essential issue of identity development, as Ashcroft and Aluhwalia (1991) argue, is the capability of the colonized to oppose, to recreate oneself as an anti-imperialist subject and that this diversion of the self should be contextualized in light that it is the development 
of identity that constitutes binaries and people are what they make themselves, regardless of the possibility of being subjects of authoritarian discourse [20]

Said (1978) utilizes Foucault's expository approach to clarify his theory of Western colonialism and its rationale of power, connecting it to works composed by Western writers about the Orient. Said uncovers, as Jan Nederveen Pieterse states, the way others are spoken to in discussion reflects winning administrations of knowledge and their truth claims, and in the process representation itself turns into a type of power;

"Edward Said (1978) applied Foucault's method of discourse analysis to the texts produced by European orientalists about the "Orient," the colonized world. In this view, the way others are represented in talk or discourse reflects prevailing regimes of knowledge and their truth claims, and in the process representation itself becomes a form of power. Foucault's post-structuralism broke with the idea of cultures as systemic structures and shifted attention to structures of knowledge within and across cultures instead." [21]

Said's point of view of identity develops through the binary relation between West and East, which is, as he calls it, Eurocentric' he concentrates on the perspective that the identity is given by Western dominion. He views truth as characterized by the people who control the power, in this way knowledge and power of the West, or colonizers, empowers them to evaluate and to arrange colonized knowledge on the grounds that this authorized them to characterize knowledge with their power. This thought leads them to regard the colonizers as unrivaled.

Thus, the fundamental point in Said's contention is that colonial individuals are settled and bound to belief system strategies of the colonizer and they have effectively affected the colonized by this rationale. Identity, then, is envisioned and arranged inside of the constraints of Western or Occidental knowledge, in light of this construction colonized are not able to recognize themselves outside this Orientalist view. Ashcroft and Alohaiwa (1991) clarify Said's contention of the cultural foundations of the West as accountable for making out these others, by distinguishing subjects from masters. Therefore, Said's concept of identity development is attached to this rationale in which he concentrates on the identity of the East. To say the colonized ought to oppose the power of the West, and reject the forced identity and the creation of one of their own, depends on this rationale as argued by Said beginning with the publication of Orientalism and in different works speculating on the importance of resistance in the postcolonial period. He imagines that the empowerment of the Western plan essentially occurred because of an absence of resistance, the reason of subordination of the Orient and to ensue after Orientalist domination. In this way, Said gives a more prominent aim of resistance during decolonization, as "the last resistance we have against the cruel practices and treacheries that deform mankind's history" [22].

Said presents a significant critical perception in The World, The Text, and the Critic (1983), in which his argument circles around the "worldliness" of the text. His term "worldliness" suggests that literary works consistently involve the surrounding circumstances that created them. Ashcroft and Ahluwalia (1991) confirm that "The paradox of Edward Said's identity is the imperative aspect of his personal 'worldliness,' a feature which affords crucial to the interests and convictions of his cultural theory" [23]. This identity is itself a text, which is continually clarified and repeated by Said, intersecting with and articulated by all the other texts he writes. Alongside these lines, worldliness is linked to the accordance with the work's root, because this agent encloses the reality of the subjects that it bears such as; marginality, dispossession, subjugation. Thus, texts to Said 
represent cultural intentions and attitudes and are not an equal interchange between these; the excursive condition, rather, resembles the "relationship between colonizer and colonized, oppressor and oppressed" [24]. Texts and words related to the world, to an extent that their capacity and usage "are matters of ownership, authority, power and the imposition of force" [25]. It is exactly from this uneven relation that "Orientalism as an academic approach emerged" [26]. Said's main basics of power relations repeat here and he argues that cultures attempt to impose their hegemony over other cultures to assert themselves through different ways [27]. Ashcroft and Ahluwalia (1991) suggest that filiations and affiliation distinguish Said's worldliness. To Said, in the modern civilization, it is hard to maintain filiations and is substituted by forms of affiliation that culture constitutes identification [28].

In this way, Said, as usual, remains in the circle of binary relation, as in his usage of the idea of affiliation and depicting of the affiliation system that binds "colonized societies to imperial culture" and within 'contrapuntal ensembles' cultural identities are comprehended"'29] to understand the meaning of contrapuntal which he borrowed from music Said elaborates;

In practical terms, 'contrapuntal reading' as I have called it means reading a text with an understanding of what is involved when an author shows, for instance, that a colonial sugar plantation is seen as important to the process of maintaining a particular style of life in England ... the point is that contrapuntal reading must take account of both processes, that of imperialism and that of resistance to it, which can be done by extending our reading of the texts to include what was once forcibly excluded [30]

In this case identities are recognized through the network of cultural system that constitutes oppositions as superior and inferior which originally created by the dominant imperial body.

This viewpoint is a marginalized understanding to identity construction. Said's reading of Western literature, from his readings of Conrad, for instance, is that the power system of the West works within the thematic formation in novels. Said relates the text to its world, which is colonialist view of the world. Though he claims a secular criticism, his viewpoints come out as a marginalized view of the world. His contention to build a true identity of the inferior is to resist the hierarchy imposition of the superior over them, to tell the reality and truth. As Ashcroft and Ahluwaia (1991) interpreted this power of resistance - to tell "truth" to oppression. Not only do humans make their truths, but "the so-called objective truth of the white man's superiority built and maintained by the classical European colonial empires also rested on a violent subjugation of African and Asian peoples" [31]

The world today is engaged with a new storm of immigrants and refugees, and everywhere people move about, leaving one place, finding another; in particular, Western countries have become tents embracing different cultures and nationalities. In such conditions a new sense of cultural identities, experiencing the feeling rootlessness and homelessness, have become the norm. Exile and the case of immigrants are reflected in Said's works as an essential basic for understanding the culture and identity in the contemporary world in reference to its strong tie with any notion of home that is left.

Said has theorized the condition of exile in many of his writings as a focal point in his ideological contention. He himself experienced homelessness and exile as a Palestinian. The sensation of immigrants and exiled people emerging from their reaction towards the new environment is totally different from what they carry from their previous background; as Said suggests, "For an exile, 
habits of life, expression, or activity in the new environment inevitably occur against the memory of these things in another environment. Thus both the new and the old environments are vivid, actual, occurring together contrapuntally" [32]. It is assumed that the idea of cultural and social identity, to Said, is a "generalized situation of being homeless" [33] that means the displacement is linked directly to identity or is bound to relocation, as in the condition of immigrants and exiled people.

I consider the significance of exile as an articulative position and structuring experience for Said's critical contention because this dissertation analyses two novels that basically focus on the identity crisis in immigrants and exile. His own critical rhetoric and his criticism are evident from the language of exile he employs. From my point of view, Said's concept of criticism can best be labeled 'exilic criticism' since it is so inflected by his experience of exile. This notion is obviously seen in the assortment of polemical literary hypothetical essays which include The World, the Text, and the Critic. In this study, I attempted to point out the instances that demonstrate the positionality of exile according to Said. However, it is in a number of Saidian notions typfied - worldliness, affiliation/filiation, and secular criticism - that he enunciates most plainly the nature of exilic criticism.

"The Saidian view of exile, emphasizes exilic displacement and emplacement over the constancy of movement in travel, and it is grounded in the postcolonial experience of loss of home which gives to it both its comparative critical distance and its ability to act in the world. Exiles, unlike travelers, bear the mark of history in their personal narratives of loss and thus desire the stability of belonging, butthat belonging must come as the result of critical, affiliative efforts to participate in collectivities. The image of exile theorized and embodied in Said's work presents us witha model of an affirmative, though not unlimited, version of human agency based in the traumatic experience of loss that is the beginning of exile." [34]

Said supported what he terms as a secular criticism over uncritical solidarity in the successive essays that compost The World, The Text, and The Critic. According to Said, recular criticism is different from religious criticism which is exemplified by endless defferal beyond the level of human comprehension. These religious critics attempt to appeal to the superhuman, the secret, the godly, the indistinct concept and the mystery in their accounts of human life [35].

Religious criticism does not examine or explain its worldly positioning. This is demonstrated in political trends for example Arab nationalism and in the writings of theorists such as Jacques Derrida who, with respect to Said, engage completely in matters of pure textuality instead of the implications of literary texts and the worldly situations. On the other hand, the foundation of secular criticism is on a grounded critical distantiation of the critic from her critical object. The secular critic is called upon to oppose, even if not necessarily decline, the entire ideological entanglements ; cultural, professional and political. The implication of this is that the effect of secular criticism cannot be decided by a specific literary perception, political system, or theoretical arrangement. Said applies the perception of affiliation, an idea that he both supports and resists, to demonstrate the manner in which the particular critical position could be accomplished. Affiliation endeavors to recover the cultural influence of filiation, the actually natural social relations, customs, family, or state, by building correlative collectivities. Symbolizing this filiative aspiration is contemporary writing which is faced by what is referred to as a crisis of filiation. Current authors 
have mapped the loss of particular filial links and affiliative endevours to restore them owing to the fear of a failure to create a subsequent generation.

Drawing from the above discussion about identity crisis, especially the contentions of Fanon and Said, the aspects of the crisis, appear as the pro colonized imitating or impersonating, as it is called mimicry, the colonizers style and way of life, feeling estrangement or alienation, and resisting the colonizers attitude and ideology. In addition, Said's idea of identity construction by the exiled and immigrant will be contrapuntal both the previous and the present cultures are taken together as they opposing each other. This aspect appears in the way when the exile resists and accepts the Western ways of life and in this is actual lose of identity; not their original and not their colonizers'. And this study will discuss them through the chosen postcolonial novels.

\section{Conclusion}

The question of identity is the most discussed and important issue in postcolonial studies. Since the end of World War II, theorists and critics have given careful consideration to the breakdown of postcolonial identities, theorizing these formations and crises. Theorists have also displayed diverse views and arguments with respect to identity arrangements associated with the procedure of decolonization and colonialism aftermaths. The development of this identification, and of locating the importance of identity and its crisis, shifts as indicated by the theorist, the period, and the way of the edge that the identity broke down has been indicated.

In postcolonial times identity is given significance because of colonialism's long stretch of conditions of depressed nations, in which new nations, liberated communities, and individuals quested for their lost identity. The importance of identity can not be found in dictionaries, because it related to the existence of the "other." Fanon began his psychoanalytic discussion of the colonized individual's confusion and lost identity, uncovering the impact colonialism left on colonial subjects and their response toward colonialism. Identity to Fanon depicted a way that colonizer treated and embedded inferiority internally, by which the colonized attempted to frame their identities by mimicking the colonizer to seem equivalent. Said surely understood this, for his Orientalism takes after Fanon's concept of the impact of colonial powers on dividing and conquering, so as to shape colonial identities of the world into two binaries, West and East: Western colonial powers purposely conveyed their belief systems about knowledge and prevalence. For Said the forced identity of this power on Eastern subjects is neither genuine nor bending; hence, he sees true identity as ideally shaped under resistance to the colonial framework, to dismiss the enforced image and backtrack to the traditional reality of Eastern character. At that point Said moves from the double relation between colonizer and colonized and seeking inbetween spaces to imagine the real nature of colonial identity.

Fanon and Said have generated a more suitable theory for dealing with the cutting-edge colonial character. Their most evident contribution to postcolonial theory comprises of their thoughts on mimicry, cultural diversity, and homeless identities. To Said there is no pure culture, yet there are diverse and real identities situated in a middle space; the genuine crisis then exists in the method for creating representatives and in its influence on identity formation. Said obsessed with the idea of the in-betweenness of postcolonial identity as Ashcoft et al(1999) argues "the in between space that Said calls interstitial space locates his understanding of cultural diversity that empowers the marginalised and exiled to compromise a position between past and present and ironically accepts and denies the other."(p.6)Consequently, the limitations between West and East, along with 
identities characterized by estrangement and its ambivalence nature; it is neither fixed nor flexible, lying somewhere in between.

To sum up, the idea of postcolonial identity presented by Fanon is about the influence of colonial system on the colonized, which made them feel inferior, whereas Said's similar idea of Fanon identities gives accord to the idea of a superior Western culture. Both Fanon and Said perceive identity as influenced by the colonial impact and the crisis occurs due to the feeling of inferiority implanted in their awareness by Western systems. Consequently, impersonating Western or colonizer behavior and style becomes one of the dilemmas of recognizing one's sense of identity. The sense of inferiority has left a deep influence in immigrants and exiles, troubling them, causing them to feel homeless and the estrangement and ambivalence toward developing a true identification.

\section{References}

[1], [3], [9] Ashcroft, B. Gareth G, and Helen, T.(1989).The Empire Writes Back: Theory and Practice in.Darby and Paolini (1994)

[19] [25] Ashcroft, Bill and Ahluwalia, P.(1999).Edward Said, London:Routledge.Print.

[2] Brockmeier, J, Donal A. C, eds.(2001).Narrative and identity: Studies in autobiography, self and culture. Vol. 1.John Benjamins Publishing.print.

[12], [14], [16], Fanon, F. (1963).The Wretched of The Earth. Trans Constance Farrington. New York: Grove Press. Print.

[17],[18] Fanon (1967) Black Skin White Masks (Translated by Charles Lam Markmann), Pluto Press.

[4] Innes, C. L.( 2007). The Cambridge Introduction to Postcolonial Literatures in English. New York: Cambridge University Press. Print.

[13] Parris, T. (2015).Being Apart: Theoretical and Existential Resistance in Africana Literature, University of Virginia Press.

[15] Richards, D. (2010). Framing Identities, A Concise Companion to Postcolonial Literature, Blackwell.

[11] Rayan, M.(2012) An Introduction to Criticism : Literature/ Film/ Culture, Wiley- Blackwell, UK.

[20], [21], [22], 23], [24] Said, E.(1978). Orientalism, New York: Pantheon.

[26] [27] [30] Said. (1993). Culture and imperialism, Vintage publishers.005. 